\title{
COMMENTS
}

\section{The Fraud Exception to the Noerr-Pennington Doctrine in Judicial and Administrative Proceedings}

Daniel J. Davis†

Imagine that two companies, Stephenson and Cushing, dominate the market for a certain drug. A new company, Flanigan, hopes soon to introduce a generic version of the drug in the United States. First, however, Flanigan must complete the Food and Drug Administration's testing and approval process. Stephenson and Cushing know that the generic drug stands to hurt their profits, and they seek to delay, or to prevent altogether, Flanigan's entry into the market. They therefore agree to file complaints with the FDA claiming fraudulently that Flanigan's product is unsafe, that its manufacturing process is unsound, and that the market should not allow in another player. Knowingly misrepresenting evidence requested by the FDA, Stephenson and Cushing successfully block Flanigan's approval. Flanigan, now shut out of the market, files a claim against Stephenson and Cushing for antitrust violations.

Under the antitrust laws, which are designed to prevent anticompetitive economic behavior, Stephenson and Cushing's actions would almost definitely be subject to liability. ${ }^{3}$ Stephenson and Cushing will, however, quickly resort to the Noerr-Pennington doctrine to avoid antitrust liability. Created by the Supreme Court in Eastern Railroad Presidents Conference $v$ Noerr Motor Freight, Inc ${ }^{4}$ and United Mine

$\dagger$ B.A. 1998, Brigham Young University; J.D. Candidate 2002, The University of Chicago.

1 This hypothetical is significantly similar to the one used in Lars Noah, Sham Petitioning as a Threat to the Integrity of the Regulatory Process, 74 NC L Rev 1, 6-11 (1995) (evaluating the potency of antitrust law and administrative procedural reform to combat the problem of sham petitioning).

2 This claim could be brought under the Sherman Act, 15 USC \$\$ 1-7 (1994).

3 See 15 USC \$ 1 . See also Radiant Burners, Inc v Peoples Gas Light \& Coke Co, 364 US 656, 659-60 (1961) (holding that a conspiracy that prevented a company from getting approval for a ceramic gas burner violated Section 1 of the Sherman Act).

4365 US 127 (1961). 
Workers $v$ Pennington, ${ }^{s}$ the Noerr-Pennington doctrine immunizes parties from antitrust liability if their "activities comprised mere solicitation of governmental action with respect to the passage and enforcement of laws." This immunity relies on the First Amendment freedom of association and right to petition the government. But would the immunity apply if Stephenson and Cushing knowingly misrepresented the information in the complaint or acted fraudulently? Although the Supreme Court has established that the Noerr-Pennington doctrine does not protect a party who has engaged in sham litigation, the Court has not determined whether Noerr-Pennington immunity extends to parties who make misrepresentations or how NoerrPennington immunity might apply to administrative agency proceedings. Dissension reigns concerning whether such an exception exists, and if it does exist, how the exception fits within existing Supreme Court jurisprudence.

A fraud exception to the Noerr-Pennington doctrine presents an important problem because many companies must participate in administrative agency and judicial proceedings to engage in business. They apply for permits and licenses, and sometimes submit their products to testing by various agencies. Companies exert strong influence in agency proceedings, which range from "rulemaking" proceedings, in which an agency acts like a legislature, to "adjudicatory" proceedings, in which an agency acts more like a court.' In particular, companies target permit applications, like in the pharmaceutical, transportation, communications, and energy industries. ${ }^{10}$ Because agencies lack the resources to verify every statement a company makes, a company can distort information submitted to agencies and thus gain a competitive advantage. This Comment offers a basic proposition: because Noerr-Pennington immunity rests on the dual principles of the First Amendment and the statutory purposes of the antitrust laws, the immunity should not extend beyond them.

The Comment presents two solutions to the fraud exception: one applies to business activity in the courts, and the other involves business activity in administrative proceedings. First, analogizing to libel law, this Comment argues that fraud and misrepresentations in judicial

\footnotetext{
5381 US 657 (1965).

6 Noerr, 365 US at 138. See also Pennington, 381 US at 670 ("Noerr shields from the Sherman Act a concerted effort to influence public officials regardless of intent and purpose.").

7 See Noerr, 365 US at 137-38.

8 See Part I.A.2.

9 See Ronald A. Cass, Models of Administrative Action, 72 Va L Rev 363, 367 (1986) (identifying this distinction as the "bipolar" model of administrative action).

10 See Noah, 74 NC L Rev at 11-14 (cited in note 1) (noting the myriad governmental agencies that must approve corporate operations).
} 
proceedings lie outside the realm of the First Amendment; thus, the Noerr-Pennington doctrine should not apply.

Second, in the administrative realm, this Comment distinguishes between political and adjudicatory agency functions based on the Administrative Procedure Act ("APA") to determine when immunity should apply. This test revolves around the fact-specific nature of the agency inquiry. Noerr-Pennington immunity should not apply when the agency proceeding involves significant factual inquiries (such as in a permit application process, where applicants must apply significant and specific factual information). Noerr-Pennington immunity should apply where the agency proceedings are designed to make broader policy determinations that do not rely as much on specific factual information. This fact-specific standard protects against fraud and misrepresentation (which lies outside the First Amendment ${ }^{12}$ ), protects agencies from receiving deliberately false information from companies (which lies inside the purposes of antitrust laws ${ }^{13}$ ), and allows the judiciary to act in its proper role as a check on the executive. ${ }^{14}$

Part I of this Comment analyzes the origins of the NoerrPennington doctrine and subsequent cases concerning fraud and misrepresentation. Part I.A specifically examines the "sham" exception to Noerr-Pennington immunity. This Part also searches for Court guidance in fraud and misrepresentation cases. Part I.B discusses the statutory framework for different administrative proceedings under the APA. Part II examines lower court dissension concerning whether a fraud exception to Noerr-Pennington immunity exists. Part III argues that a fraud and misrepresentation exception should apply in judicial proceedings based on recognized First Amendment limitations. This Part examines First Amendment jurisprudence, particularly libel law, to determine the outer boundaries of the right to petition. It then considers how fraud and misrepresentation fit into that jurisprudence. Part IV presents the solution involving administrative agency proceedings. Using the administrative proceedings framework in Part I.B, this Comment presents a fact-specific standard to determine when a business's involvement in an agency proceeding should subject that entity to antitrust liability.

11 Pub L No 89-554, 80 Stat 381 (1966), codified at 5 USC $\$ \S 551$ et seq (1994).

12 See, for example, McDonald v Smith, 472 US 479, 484 (1985) (finding no protection for false statements of fact in the First Amendment). See also Part III.A.

13 The antitrust laws were meant to encourage fair competition and to provide the government with adequate means to monitor that competition accurately. See text accompanying notes $15-16$.

14 See Part IV.B.2. 


\section{SUPREME COURT JURISPRUDENCE UNDER THE NOERR-PENNINGTON DOCTRINE}

The antitrust laws give government broad power to prohibit "combinations or conspiracies in restraint of trade or commerce, the monopolization of trade or commerce or attempts to monopolize the same." ${ }^{\prime 15}$ This power is intended to protect free competition by forcing companies to allocate their resources to create the highest quality products at the lowest possible prices. ${ }^{16}$ The reach of the antitrust laws, however, has some limits.

The Noerr-Pennington doctrine presents one limit on antitrust law-it protects companies' lobbying efforts. To this extent, the NoerrPennington doctrine reflects First Amendment guarantees of free speech and freedom to petition the government. This Part discusses the key cases that created and interpreted the Noerr-Pennington doctrine.

\section{A. The Noerr-Pennington Doctrine}

1. The early cases.

In Noerr, a group of Pennsylvania truckers alleged that several railroads and the Eastern Railroad Presidents Conference engaged in a conspiracy in violation of the Sherman Act. ${ }^{17}$ Specifically, the truckers alleged that the railroads launched a negative publicity campaign against truckers; the aim of which was to damage the trucking business, including existing relationships between truckers and their customers. ${ }^{18}$ The defendants counterclaimed by stating much the same of the truckers. ${ }^{19}$ The district court found against the railroad company because its campaign was "malicious and fraudulent." ${ }^{20}$ The railroads

1515 USC $\$$ 1-2. See D.R. Wilder Manufacturing Co v Corn Products Refining Co, 236 US 165, 173-74 (1915) (stating the intended breadth of the Sherman Act).

16 See Northern Pacific Railway Co v United States, 356 US 1, 4 (1958):

[The antitrust laws] rest[] on the premise that the unrestrained interaction of competitive forces will yield the best allocation of our economic resources, the lowest prices, the highest quality and the greatest material progress, while at the same time providing an environment conducive to the preservation of our democratic political and social institutions.

17 Noerr, 365 US at 129.

18 Id. The Court found that the aim of the campaign was "to foster the adoption of laws and law enforcement practices destructive of the trucking business, to create an atmosphere of distaste for the truckers among the general public, and to impair the relationship between the truckers and their customers." Id.

19 Id at 132 (stating that the defendants claimed the truckers had conspired to "destroy the railroads' competition in the long-distance freight business and to monopolize that business for heavy trucks").

20 Id at 133. The Supreme Court explained: "The District Court did not expressly find that any particular part of the railroads' publicity campaign was false in its content. Rather, it found that the technique of the railroads was 'to take a dramatic fragment of truth and by emphasis and 
admitted to conducting a campaign to influence the passage of state laws relating to truck weight limits and tax rates on heavy trucks, but they maintained they had no desire to destroy the trucking business as a competitor nor to interfere with trucker-customer relationships. ${ }^{21}$

The Supreme Court found for the railroad on two separate grounds. First, the Sherman Act neither regulated political activity nor infringed on the concept of representation. " Second, holding against the railroads "would raise important constitutional questions" about the right to petition the government. ${ }^{23}$ The Court recognized that groups with a significant interest in the outcome of certain legislation often provide important information to Congress about the issues in question. ${ }^{24}$ The unethical tactics used in the publicity campaign were of no moment to the Court. ${ }^{25}$ Pennington upheld the same immunity doctrine where coal companies and unions successfully persuaded the Secretary of Labor to establish minimum wages for employees of contractors, thereby frustrating the non-unionized companies' attempts to compete in the coal market. ${ }^{26}$

Noerr-Pennington's scope expanded under California Motor Transport Co v Trucking Unlimited. In California Motor, highway carriers alleged an antitrust conspiracy by other highway carriers to "institute state and federal proceedings," including "rehearings and [ ] reviews or appeals from agency or court decisions," to prevent the plaintiff from receiving operating rights or to transfer or register those rights. ${ }^{28}$ The Court extended Noerr-Pennington immunity to administrative proceedings. ${ }^{20}$ California Motor also made important strides toward revealing when the Court would disallow immunity.

repetition distort it into falsehood." Id at $133 \mathrm{n} 8$ (citation omitted and emphasis added).

21 Id at 131.

22 Id at 137:

To hold that the government retains the power to act in this representative capacity and yet hold, at the same time, that the people cannot freely inform the government of their wishes would impute to the Sherman Act a purpose to regulate, not business activity, but political activity, a purpose which would have no basis whatever in the legislative history of that Act.

23 Id at 138. See US Const Amend I ("Congress shall make no law ... abridging ... the right of the people ... to petition the Government for a redress of grievances.").

24 Noerr, 365 US at 139.

25 Id at 145 (holding that "deception [of public officials], reprehensible as it is, can be of no consequence so far as the Sherman Act is concerned").

26 Pennington, 381 US at 660, 670.

27404 US 508 (1972).

28 Id at 509.

29 Id at 510 ("The [Noerr-Pennington doctrine] governs the approach of citizens or groups of them to administrative agencies (which are both creatures of the legislature, and arms of the executive) and to courts, the third branch of Government. Certainly the right to petition extends to all departments of the Government."). See also Part I.B.

30 Id at 515 ("First Amendment rights may not be used as the means of the pretext for achieving 'substantial evils."'), quoting NAACP v Button, 371 US 415, 444 (1963). 
In discussing unethical conduct, the Court clarified that several actions could result in sanctions. The Court relied on language in Noerr stating that when a business used political activity as a "sham" solely to harm a competitor, antitrust liability would survive the immunity challenge. ${ }^{31}$ Citing several cases, the Court showed that fraud, conspiracy, and bribery could all create antitrust liability. ${ }^{32}$ One example the Court relied upon was perjury of witnesses. ${ }^{33}$ The Court then stated in dictum that " $[\mathrm{t}]$ here are many other forms of illegal and reprehensible practice which may corrupt the administrative or judicial processes and which may result in antitrust violations. Misrepresentations, condoned in the political arena, are not immunized when used in the adjudicatory process. ${ }^{34}$ With little explanation of these statements and the scope of this sham exception, the Court concluded the highway carriers' alleged actions could be subject to antitrust liability.

\section{The sham exception clarified.}

The Court at last established the scope of the sham exception in the litigation setting in Professional Real Estate Investors, Inc $v$ Columbia Pictures Industries, Inc. ${ }^{36}$ Noting that "a successful effort to influence government action ... certainly cannot be characterized as a sham," ${ }^{, 37}$ the Court outlined a two-part test for determining when litigation is a sham and thus unprotected by Noerr-Pennington immunity:

The first step is to ask whether the lawsuit is "objectively baseless $\ldots$ in the sense that no reasonable litigant could realistically expect

31 See Noerr, 365 US at 144:

There may be situations in which a publicity campaign, ostensibly directed toward influencing governmental action, is a mere sham to cover what is actually nothing more than an attempt to interfere directly with the business relationships of a competitor and the application of the Sherman Act would be justified.

32 California Motor, 404 US at 512-13. The fraud point, in particular, will become important. See Part III. See also Walker Process Equipment, Inc v Food Machinery \& Chemical Corp, 382 US 172, 175-77 (1965) (holding that the enforcement of a patent procured by fraud on the patent office may violate the Sherman Act, provided the other elements necessary to a Sherman Act case are present); Continental Ore Co v Union Carbide \& Carbon Corp, 370 US 690, 707-08 (1962) (holding that conspiracy with a licensing authority to eliminate a competitor may also result in an antitrust transgression); Rangen, Inc $v$ Sterling Nelson \& Sons, 351 F2d 851, 857 (9th Cir 1965) (holding that bribery of a public purchasing agent may constitute an antitrust violation).

33 California Motor, 404 US at 512.

34 Id at 513.

35 Id at 516. Because the district court granted defendants' motion for summary judgment, the Court evaluated only the plaintiffs' complaint but concluded that the plaintiffs' allegations came within the sham exception and remanded for trial. Id.

36508 US 49 (1993) (involving a dispute as to whether hotels' rental of video discs to guests violated prohibition of retransmission without a license).

37 Id at 58, citing Allied Tube \& Conduit Corp v Indian Head, Inc, 486 US 492, 502 (1988) and Vendo Co v Lektro-Vend Corp, 433 US 623,645 (1977) (Blackmun concurring in result). 
success on the merits." If If the lawsuit is "reasonably calculated to elicit a favorable outcome," Noerr-Pennington immunity applies.

Second, if the litigation is objectively baseless, then liability depends on the subjective intent of the party. If the litigation "conceals an attempt to interfere directly with the business relationships of a competitor through the use of the governmental process-as opposed to the outcome of that process," Noerr-Pennington immunity fails. ${ }^{40}$ Even without the immunity, however, the plaintiff must still show an antitrust claim. ${ }^{41}$

The Court did not explain how fraud or misrepresentation would play into a determination of either of the two steps of the sham litigation test. The Professional Real Estate Court did not elaborate on how fraud affected a determination that a suit was "objectively baseless" or the subjective intent of the party. Unlike California Motor, which implied that fraud could create antitrust liability, the Court stated, "We need not decide here whether and, if so, to what extent Noerr permits the imposition of antitrust liability for a litigant's fraud or other misrepresentations." ${ }^{43}$ Because the Court did not provide guidance on how to handle fraud or misrepresentation in litigation and other contexts, the lower courts are in disarray. ${ }^{4}$

\section{B. Noerr-Pennington Cases Involving Agency Proceedings}

Companies also face potential antitrust violations for their actions in administrative proceedings. The APA acts as the default system for agency proceedings in promulgating rules and regulations. It defines broadly the scope and character of administrative agency actions. It integrates aspects of legislative and judicial proceedings. ${ }^{45}$ The

38 Id.

39 Id.

40 Id at 60-61 (citations and internal quotation marks omitted).

41 Id at 61:

[E]ven a plaintiff who defeats the defendant's claim to Noerr immunity by demonstrating both the objective and the subjective components of a sham must still prove a substantive antitrust violation. Proof of a sham merely deprives the defendant of immunity; it does not relieve the plaintiff of the obligation to establish all other elements of his claim.

42404 US at 512-13 (stating that using patents obtained by fraud to exclude potential competitors would violate the antitrust laws).

43508 US at 62 n 6 . After this proposition, the Court cited FRCP 60(b)(3) (allowing a federal court to "relieve a party ... from a final judgment" for "fraud ... misrepresentation, or other misconduct of an adverse party") and Walker Process Equipment, Inc v Food Machinery \& Chemical Corp, 382 US 172, 176-77 (1965) (stating that fraud in patent litigation could lead to an antitrust violation).

44 See Part II.

45 See U.S. Department of Justice, Attorney General's Manual on the Administrative Procedure Act 14 (1947):

[T]he entire Act is based on a dichotomy between rule making and adjudication .... Rule 
distinctions it makes between different parts of proceedings are important in determining how far antitrust liability reaches into the administrative realm. ${ }^{46}$ This Part will first discuss various APA provisions and then analyze how the Supreme Court has treated agency actions in antitrust cases.

The APA separates administrative proceedings into two worlds depending on whether they result in "rules" or "orders." future effect and are "designed to implement, interpret, or prescribe law or policy.", On the other hand, orders, like judicial decisions, constitute "final disposition[s]" of current controversies." Rulemaking proceedings lead to rules, and adjudicatory proceedings lead to orders. $^{\text {so }}$

Rulemaking and adjudicatory processes follow different procedures. The rulemaking process requires that the administrator give public notice of the proceeding, provide an opportunity for interested parties to comment on the subject of a rulemaking, and include in the final rule a brief statement of the reason for its adoption. ${ }^{\text {s1 }}$ The adjudicatory process, in contrast, tends to follow a more formalized procedure and resembles a judicial proceeding. Parties to adjudication receive notice of the proceeding and participate more extensively in producing and contesting the information on which the decision is based than do parties in rulemaking. ${ }^{52}$ The APA's language lends support to the view that adjudications should resemble trials. For example, in adjudications, "[a] party is entitled to present his case or defense by oral or documentary evidence, to submit rebuttal evidence, and to conduct such cross-examination as may be required for a full and true disclosure of the facts." ${ }^{, 53}$ The adjudication provisions also address burdens of proof and rules of evidence, ${ }^{s}$ allude to discovery procedures, ${ }^{3 s}$ regulate the form of the decision, ${ }^{\text {sh }}$ require a transcript of the

making is ... essentially legislative in nature, not only because it operates in the future but also because it is primarily concerned with policy considerations. The object of the rule making proceeding is the implementation or prescription of law or policy for the future, rather than the evaluation of respondent's past conduct .... Conversely, adjudication is concerned with the determination of past and present rights and responsibilities.

See Part IV.

5 USC $§ 551$ (1994).

Id $\S 551(4)$.

Id $\S 551(6)$.

See id § 551(4)-(7).

Id $\S 553$ (1994).

Id $\$ \S 554,556,557$ (1994).

Id $\S 556(d)$.

See id.

See id \$ 556(c).

See id $\$ 557$. 
proceedings, ${ }^{57}$ and mandate that the decision be based on the record and "supported by ... reliable, probative, and substantial evidence."ss

The break between adjudications and rulemaking procedures is not perfectly clean. The APA permits a more informal rulemaking procedure as well as a more informal adjudication procedure. In some rulemaking proceedings, for example, the APA allows interested parties to participate in rulemaking by submitting written evidence or arguments and by requiring agencies to articulate the basis of their decision. ${ }^{59}$ Exceptions also exist to the requirement of a trial-type hearing in adjudicatory proceedings. ${ }^{60}$

Almost every section of the APA contains exceptions such that the formal rigors of adjudication or rulemaking do not apply to certain types of decisions. The adjudication provision, for example, makes exceptions for certain personnel decisions, determinations based on inspections or tests, and matters pertaining to military and foreign affairs. ${ }^{61}$ The rulemaking section contains a general exception for some matters and specific exceptions to its notice, hearing, and publication requirements. ${ }^{62}$ Since the APA acts only as a default set of rules for agency proceedings, some federal statutes mandate that certain agencies use hybrid processes that combine legislative and adjudicatory procedures. ${ }^{63}$ In addition, the APA does not mandate that an agency must take a particular avenue in its policy formulation. Administrative proceedings, therefore, can exhibit characteristics of both legislative and judicial actions.

The Court's varying treatment of administrative agencies in Noerr-Pennington cases reflects this legislative-judicial distinction. In California Motor, the Court allowed Noerr-Pennington immunity to extend to administrative agencies. ${ }^{6+}$ The decision protected the rights of association and petition. The reach of the Noerr-Pennington doc-

57 Id $\S 556(\mathrm{e})$.

58 Id $\S 556(d)$.

59 Id $\S 553(\mathrm{c})$.

60 See id $\$ 554(\mathrm{a})$.

61 Id $\S 554(\mathrm{a})(2)-(4)$.

62 See id $\$ 553(\mathrm{a})-(\mathrm{b})$, (d)

63 See, for example, Magnuson-Moss Warranty-Federal Trade Commission Improvement Act, Pub L No 93-637, 88 Stat 2183 (1975) § 202(a), codified as amended at 15 USC § 57a(c) (1994) (outlining a procedure for informal hearings); Endangered Species Act, Pub L No 93-205, 87 Stat 884 (1973), codified as amended at 16 USC $\$ 1533$ (1994) (setting different procedures for promulgating regulations to determining whether to list a species as threatened or endangered).

64404 US at 510 (identifying administrative agencies as "both creatures of the legislature, and arms of the executive").

65 Id at 510-11 ("We conclude that it would be destructive of rights of association and of petition to hold that groups with common interests may not, without violating the antitrust laws, use the channels and procedures of state and federal agencies and courts to advocate their causes and points of view."). 
trine in administrative proceedings, however, is unknown. The Court attempted to distinguish between "political activities" and "conduct in the setting of the adjudicatory process." Quoting Noerr, the Court emphasized the extreme caution necessary in imputing to legislation the ability to curtail First Amendment rights.

The Court noted that in an adjudicatory process, however, "unethical conduct ... often results in sanctions.... There are many other forms of illegal and reprehensible practice which may corrupt the administrative or judicial processes and which may result in antitrust violations." ${ }^{\circ 8}$ The Court qualified this language, stating that both parties have the right of access to agencies "within the limits ... of their prescribed procedures." $"$ Indeed, the cases recognize that antitrust liability can occur if a fact-finder has concluded that the administrative and judicial processes have been abused. ${ }^{70}$ The Court has not elaborated further on this distinction. "Because of the Court's lack of clarity, lower courts have not achieved consensus in interpreting these precedents.

\section{COMPETING INTERPRETATIONS OF FRAUD AND MISREPRESENTATION IN NOERR-PENNINGTON JURISPRUDENCE}

In the years following Professional Real Estate, courts have taken opposing approaches to fraud and misrepresentation in antitrust proceedings. Some courts ignore the misrepresentations and apply NoerrPennington immunity. Others have treated fraud and misrepresentation as independent grounds for denying Noerr-Pennington immunity.

\section{A. The Third Circuit Ignores Fraud in Armstrong}

One view of fraud advanced by courts is that agencies have significant protections against fraud, so a fraud exception is unnecessary. The Third Circuit addressed misrepresentation in the administrative setting in Armstrong Surgical Center, Inc v Armstrong County Memorial Hospital. ${ }^{2}$ Pursuant to statute, the plaintiff, in order to construct a new outpatient center, had to obtain a Certificate of Need ("CON")

66 Id at 512.

67 Id, quoting Noerr, 365 US at 141 ("Congress has traditionally exercised extreme caution in legislating with respect to problems relating to the conduct of political activities.").

68 California Motor, 44 US at 512-13.

69 Id at 515.

70 Professional Real Estate, 508 US at 58, citing California Motor, 404 US at 513. The context of this discussion is where a party has pursued a policy of filing "a pattern of baseless, repetitive claims." Professional Real Estate, 508 US at 58, citing California Motor, 404 US at 513. This concession is important because it shows that the Court has left a gap open for courts to consider whether or not the adjudicatory process itself has been abused.

71 See text accompanying notes 34-35.

72185 F3d 154 (3d Cir 1999), cert denied, 530 US 1261 (2000). 
from the Pennsylvania Department of Health. ${ }^{73}$ The CON process includes "an extensive proceeding consisting of an investigation, an evaluation of submitted materials, and a public hearing" to determine whether a new center would be needed and to ensure the new facility would not cause a needless duplication of services. ${ }^{74}$ The plaintiff alleged that the defendant hospital made misrepresentations in the CON process that resulted in the denial of their certificate. ${ }^{75}$ Specifically, the plaintiff alleged that the hospital misled the Department when the hospital claimed that it would open its own outpatient center when, in fact, it had halted construction on the facility and did not plan to resume. ${ }^{76}$ The plaintiff also alleged that the hospital's physicians claimed falsely to the Department that they would not use the plaintiff's proposed outpatient center. ${ }^{n}$

The court held that Noerr-Pennington immunity protected the hospital from antitrust liability. ${ }^{78}$ The court began with the proposition that antitrust laws regulate business, not politics." The court disregarded the sham petition exception because the plaintiff never alleged that the petitioning conduct was for any purpose other than obtaining favorable government action, and the sham exception applied solely to the use of the governmental process itself to engage in anticompetitive conduct. ${ }^{87}$ Therefore, because the injury came from the denial of the $\mathrm{CON}$, not the process of obtaining the CON, no liability resulted. ${ }^{81}$

In turning to the misrepresentation question, the Third Circuit began by pointing out that Professional Real Estate left the issue open." In part relying on the supposition that "deception, reprehensible as it is, can be of no consequence so far as the Sherman Act is con-

73 Id at 156. See also Health Care Facilities Act, 35 Pa Stat Ann $\S 448.701$ (a)(2) (Purdon 1993).

74 Armstrong, 185 F3d at 156.

75 Id.

76 Id.

77 Id.

78 Id at 164 (declining to look behind the administrative agency's decisions because the hospital engaged solely in political activity).

79 Id at 158 (referring to Noerr as supporting "'the principle that the antitrust laws regulate business, not politics"'), quoting City of Columbia v Omni Outdoor Advertising, 499 US 365, 383 (1991).

so Armstrong, $185 \mathrm{~F} 3 \mathrm{~d}$ at 158 (comparing the anticompetitive use of governmental process with the outcome of that process).

81 Id at 160 ("Each of the injuries the plaintiff claims is a direct result of the Department's decision to deny the plaintiffs application for a CON.... [Thus] antitrust liability cannot be imposed on a private party who induced the state action.").

82 Id. The Third Circuit also cited Omni, 499 US at 377, for the proposition that "[s]uch a rule [disallowing Parker immunity for corruption, bribery, or other violations of state and federal law] would call upon the antitrust courts to speculate as to whether state action purportedly taken in the public interest was the product of an honest judgment or desire for private gain." Id at 161 . The approach had the virtue of practicality but the vice of being unrelated to the purposes of the Sherman Act and the antitrust state action doctrine. Armstrong, $185 \mathrm{~F} 3 \mathrm{~d}$ at 161. 
cerned, ${ }^{, 83}$ the court avoided looking into the particulars of the agency decision. ${ }^{84}$ The statute authorized the Department of Health to regulate the number, size, and spacing of health care facilities. ${ }^{85}$ The Department was "disinterested, conducted their own investigation, and afforded all interested parties an opportunity to set the record straight.," ${ }^{, 85}$ It issued findings to support its conclusion that the proposed center was not in the public interest. ${ }^{87}$ Although the ruling did not include a specific finding on the misrepresentation, the Department heard evidence on it and made a credibility determination. ${ }^{8 s}$ Any party who thought a fraud had been committed could have moved to reopen the proceedings to determine if the Department was misled. Armstrong thus stands for two propositions: 1) that the agency has enough valid checks to prevent fraud and misrepresentations from tainting a decision, and 2) that courts should not inquire into the validity of agency decisions under the auspices of the antitrust laws. Fraud and misrepresentation, therefore, do not nullify the Noerr-Pennington doctrine, according to the Third Circuit.

\section{B. Fraud and Misrepresentation as Independent Grounds for Eliminating Noerr-Pennington Immunity}

The other main approach treats fraud and misrepresentation as separate from the sham exception. Under this theory, a court does not look to the two-part sham exception test in Professional Real Estate. Rather, fraud and misrepresentation independently nullify the NoerrPennington doctrine. Kottle v Northwest Kidney Center" and Whelan $v$ $A b e l^{2}$ follow this strand of reasoning.

83 Armstrong, 185 F3d at 162, citing Noerr, 365 US at 145.

84 The Third Circuit also relied on the antitrust state action doctrine of Parker $v$ Brown, 317 US 341 (1943). Armstrong, 185 F3d at 161-62. The state action doctrine states that the Sherman Act does not extend to actions made by states to restrain commerce. Parker, 317 US at 352. However, that doctrine involves federalism principles that are beyond the scope of this Comment.

85 Armstrong, $185 \mathrm{~F} 3 \mathrm{~d}$ at 162 . See note 73.

86 Armstrong, 185 F3d at 163.

87 Id.

88 Id ("[T]he record reflects that the decision makers recognized that there was a dispute and made a credibility determination concerning it.").

89 Id (stating that Pennsylvania law authorizes reopening of administrative proceedings by the agency "whenever the public interest requires").

90 See Part I.A.2.

91146 F3d 1056, 1059-64 (9th Cir 1998) (considering the Noerr-Pennington doctrine in conjunction with state and federal antitrust law claims and an administrative proceeding).

9248 F3d 1247, 1260 (DC Cir 1995) (holding that Noerr-Pennington does not bar claims of malicious prosecution, abuse of process, and tortious interference when plaintiff alleges that defendants made deliberately false statements). 
Kottle, like Armstrong, involved a CON application. ${ }^{93}$ Also, as in Armstrong, the process for receiving a CON involved an extensive statutorily mandated process. ${ }^{\text {s. }}$ Northwest blocked Kottle's CON application and Kottle sued, claiming Northwest made false statements and misrepresentations in the hearing. ${ }^{95}$ The court identified three possible exceptions to Noerr-Pennington immunity. The first was the twopart sham litigation test of Professional Real Estate. ${ }^{96}$ The second exception would be met if a series of lawsuits had been filed "pursuant to a policy of starting legal proceedings without regard to the merits and for the purpose of injuring a market rival." "Finally, sham litigation could be found if "a party's knowing fraud upon, or its intentional misrepresentations to, the court deprive the litigation of its legitimacy."

Recognizing that the current suit involved an administrative agency instead of a court, the analysis turned on "whether the executive entity in question more resembled a judicial body, or more resembled a political entity." The court noted that, on both the federal and state levels, administrative decisions vary from highly structured procedural decisions by the agency to highly discretionary decisions by trade negotiators or advisers; therefore, a "totality of the circumstances" test should apply to the judicial versus political analysis. ${ }^{100}$ Finding that the CON procedure resembled an adjudicatory proceeding, the court applied the three tests for the sham exception. ${ }^{101} \mathrm{Al}-$ though the court eventually found against the plaintiff, the Kottle

93146 F3d at 1058. However, this proceeding was in Washington State, not in Pennsylvania, as was Armstrong.

94 Id. After receiving a CON application, the Department can conduct a public hearing. At the hearing, oral and written evidence can be presented by the petitioner along with responses from other health care facilities that provide similar services. If petitioner is denied, he has the right to appeal the decision. Id. See text accompanying notes $72-74$ for the CON proceeding in Armstrong.

95 Id at 1060.

96 Id ("[T]he antitrust plaintiff must demonstrate that the lawsuit was (1) objectively baseless, and (2) a concealed attempt to interfere with the plaintiff's business relationships.").

97 Id, quoting USS-POSCO Industries v Contra Costa County Building \& Construction Trades Council, 31 F3d 800, 811 (9th Cir 1994).

93 Kottle, 146 F3d at 1060, citing Liberty Lake Investments, Inc v Magnuson, 12 F3d 155, 158 (9th Cir 1993). See also Clipper Exxpress v Rocky Mountain Motor Tariff Bureau, Inc, 690 F2d 1240,1260 (9th $\mathrm{Cir} 1982$ ) (discussing the threat that false information presents to the "fair and impartial functioning" of agency proceedings).

99 Kottle, $146 \mathrm{~F} 3 \mathrm{~d}$ at 1061 . Whether an administrative agency resembles a judicial or legislative body is the core concern in determining whether antitrust liability applies. See Part IV.

100 Kottle, 146 F3d at 1062.

101 Id at 1062-63 (specifically (1) whether the advocacy was "objectively baseless," (2) whether there was a pattern of behavior, or (3) whether the misrepresentations deprived the process of legitimacy). 
framework established that fraud or misrepresentation by itself could eliminate Noerr-Pennington immunity. ${ }^{102}$

Other cases have given fraud and misrepresentation weight in determining Noerr-Pennington immunity. ${ }^{103}$ For example, in Whelan, the D.C. Circuit held that Noerr-Pennington immunity did not apply to deliberately false statements made to state securities officials. ${ }^{104}$ Instead of using the two-part sham exception test in Professional Real Estate, the D.C. Circuit found the false statements deprived the defendant of Noerr-Pennington immunity. ${ }^{105}$

Several concepts have been advocated in trying to fill in the gap created in Professional Real Estate. ${ }^{106}$ All have their weaknesses and strengths, but the myriad of conclusions begs for a more comprehensive standard in determining the place of fraud or misrepresentations allegations in response to Noerr-Pennington immunity.

\section{A FRAMEWORK FOR EVALUATING FRAUD AND MISREPRESENTATION CLAIMS IN THE JUDICIAL SETTING}

The judicial context provides the easier case to advocate a fraud and misrepresentation exception to the Noerr-Pennington doctrine. Courts can already rely on significant precedent regarding the sham exception and fraud.

Noerr-Pennington immunity rests on two self-enforcing propositions: the right to petition the government and the right to engage in political activity. ${ }^{100}$ To the extent that fraud and misrepresentation take a party outside these two rights, courts can impose antitrust liability. In other words, if the First Amendment does not protect fraud or misrepresentation, then the Noerr-Pennington doctrine cannot protect them, either. This Part will examine the limits of these rights.

102 Id at 1063 (holding that the allegations of misrepresentation were not specific enough to overcome First Amendment concerns).

103 See, for example, Liberty Lake, 12 F3d at 159 (stating that note 6 in Professional Real Estate made the two-part sham test inapplicable where there was proof that a party's fraud or misrepresentations had deprived the court's opinion of legitimacy).

104 Whelan, 48 F3d at 1254-55 ("[W]e find that neither Noerr-Pennington nor the First Amendment protects the conduct plaintiffs have alleged-namely, knowing misrepresentations to state securities administrators and a federal court.").

105 Id at 1255 (finding that misrepresentations in an adjudicatory process are beyond the protection of Noerr-Pennington).

106 See text accompanying notes 38-41.

107 See text accompanying notes 22-26.

108 Excellent discussions of the right to petition the government already exist. See, for example, Raymond $\mathrm{Ku}$, Antitrust Immunity, The First Amendment and Settlements: Defining the Boundaries of the Right to Petition, 33 Ind L Rev 385, 389-403 (2000) (discussing the historical roots of the right to petition and its potential scope under Noerr-Pennington); Gary Myers, Antitrust and First Amendment Implications of Professional Real Estate Investors, 51 Wash \& Lee L Rev 1199, 1234-41 (1994) (discussing the right to petition and its relationship with NoerrPennington). Such deep doctrinal discussions of the roots of the doctrine are outside the scope of 


\section{A. The Limits of the Right to Petition}

The right to petition extends to all branches of government. ${ }^{100}$ Like other First Amendment protections, the right to petition is limited in scope. Although the First Amendment protects theoretical discussions and ideas, false statements of fact do not enjoy the same immunity: "neither the intentional lie nor the careless error materially advances society's interest in uninhibited, robust, and wide-open debate on public issues." ${ }^{110}$ The Court has adopted this analysis in the realm of libel and defamation law, where the First Amendment right is balanced against the "individual's right to the protection of his own good name." ${ }^{\text {III }}$ This right to protect one's reputation is based on a respect for "the essential dignity and worth of every [individual]." McDonald v Smith, ${ }^{1,3}$ the Court concluded that the right to petition did not rise to the level of an "unqualified right to express damaging falsehoods."

Since the right to petition does not cover everything a party might say, the question then becomes what standard should determine what is covered. Petitions to any governmental body containing "intentional and reckless falsehoods do not enjoy constitutional protection." "115 The standard accords with the one announced in New York Times Co $v$ Sullivan ${ }^{116}$ as "actual malice": knowledge at the time the words were false, or with reckless disregard of whether they were false. ${ }^{117}$

Evidence of this position abounds in the judicial rules and decisions. Legal judgments procured through fraud, misrepresentation, or other misconduct of an adverse party may be set aside. ${ }^{118}$ Patents obtained by knowing and willful fraud are nullified because the patent . process's purpose has been frustrated. ${ }^{119}$ Perjury is an obvious example of testimony being nullified because of its misrepresentations. ${ }^{120}$

this Comment. The Comment merely intends to pick up the relevant points of the doctrine as they relate to antitrust and administrative agencies.

109 California Motor, 404 US at 510.

110 Gertz $v$ Robert Welch, Inc, 418 US 323, 340 (1974).

111 Id at 341.

112 Id, quoting Rosenblatt v Baer, 383 US 75, 92 (1966).

113472 US 479 (1985).

114 Id at 484.

115 Id, citing Garrison v Louisiana, 379 US 64, 75 (1964).

116376 US 254 (1964).

117 Id at 279-80.

118 See, for example, FRCP 60(b)(3) (allowing a court to relieve a party of final judgment, order, or proceeding procured through fraud, misrepresentation, or other misconduct). See also FRCP 11(b)(3) (allowing for sanctions if attorneys present factual allegations that do not have evidentiary support or are not likely to have evidentiary support after a reasonable opportunity for further investigation and discovery).

119 See Nobelpharma AB v Implant Innovations, Inc, 141 F3d 1059, 1069-70 (Fed Cir 1998) 
B. Fraud and Misrepresentation in the Antitrust Realm

The analysis underlying fraud and misrepresentation goes handin-hand with the sham exception because both apply when the governmental process has been tainted through improper use. The sham exception applies where a party uses "the governmental process-as opposed to the outcome of that process-as an anticompetitive weapon." ${ }^{\text {,21 }}$ Fraud and misrepresentation create a judicial outcome based on incorrect information that also may act as a bar to entry for other competitors. In both cases, a party has abused the judicial process to give itself an unfair advantage over a competitor.

A tort law analogy shows how fraud and misrepresentation disrupt the judicial process. The tort of abuse of process is available to a plaintiff who can show the presence of an ulterior motive and an overt act that is improper in the ordinary course of a proceeding. ${ }^{12}$ This tort provides a remedy if legal procedure has been set in motion in proper form, with probable cause, and even with ultimate success, but has been perverted to accomplish an ulterior purpose. ${ }^{123} \mathrm{~A}$ business, intending to keep its competitor out of the market by crippling it with litigation costs or an adverse judgment, could use misrepresentations to distort litigation and procure a favorable outcome. ${ }^{124}$ Thus, the existence of the tort of abuse of process shows that the right to petition or engage in political activity does not have an unlimited extension. Fraud and deliberate misrepresentations should therefore be acceptable grounds to eliminate Noerr-Pennington immunity in the judicial setting. Fraud and misrepresentation place an action outside the realm of the right to petition on which Noerr-Pennington is based.

The best standard for determining whether an action constitutes fraud or misrepresentation for purposes of the Noerr-Pennington doc-

(holding that antitrust liability extended to a patentee who engaged in willful and knowing fraud on the PTO). This case seems to extend principles enumerated in Walker to include "inequitable conduct" as well as fraud. Id (noting that inequitable conduct "is a broader, more inclusive concept" than fraud).

120 California Motor, 404 US at 512 (discussing perjury as an example of conduct that results in litigation sanction).

121 City of Columbia v Omni Outdoor Advertising, Inc, 499 US 365, 380 (1991).

122 See W. Page Keeton, et al, Prosser and Keeton on the Law of Torts $\$ 121$ at 897-900 (West 5th ed 1984).

123 Id.

124 In many situations, a plaintiff may bring an abuse-of-process tort suit as well. So why not just let plaintiffs bring an abuse of process tort action? First, it is not clear how well the tort claim and the fraud claim would map onto each other. There may be a large number of cases in which courts find that anticompetitive intent is an ulterior motive or that fraud or misrepresentation constitutes an overt act. Also, the antitrust claim has the unique feature of exposing the liable party to treble damages, which should act as a proper deterrent to parties who knowingly provide false information in judicial proceedings. See 15 USC $\$ 15$ (stating that plaintiffs in antitrust suits can recover treble damages and the cost of the suit, including attorney's fees). 
trine is the New York Times malice standard. ${ }^{125}$ Little difference exists between the libel and antitrust contexts. ${ }^{126}$ Using the libel standard also gives courts case law to draw upon in determining what actions constitute malice. Since the malice standard does not trample on the First Amendment right to petition, courts using it in the Noerr-Pennington context can ensure that the exception does not overwhelm the immunity.

Although similarities exist between libel law and the antitrust context, a plaintiff cannot bring a libel suit in all cases in which antitrust liability may apply. Libel suits involve accusations about the character or qualities of another person. ${ }^{127}$ In many antitrust cases, however, the fraud or misrepresentation at issue is something the company has said about itself. In Armstrong, for example, the issue concerned the defendant hospital's representations of its own medical facilities and capabilities. ${ }^{128}$ Thus, antitrust law covers more situations than libel law covers. ${ }^{120}$

This reasoning goes directly against Armstrong's assertion that deceit and other misrepresentations can go unchecked by the judiciary. ${ }^{130}$ Kottle comes closest to this standard in allowing fraud and misrepresentations to eliminate Noerr-Pennington immunity. ${ }^{132}$ Kottle, however, does not determine the standard for intent. McDonald requires a malice standard. ${ }^{132}$ Other courts emphasize that the party must still show an antitrust injury. ${ }^{133}$ This should not be surprising - in a libel

125 See text accompanying notes 115-17.

126 In both situations, an entity knowingly uses false information to harm another. A company's knowing misrepresentations about itself or another company create the same injurious result upheld in a libel action.

127 See McDonald, 472 US at 483-84 (noting that the right to petition is cabined by libel law).

128 See text accompanying notes 75-78.

129 Also, in order to prevent chilling of the right to petition, broad allegations of fraud and misrepresentation should not be allowed to survive summary judgment. In fact, the Federal Rules require particularity in fraud pleadings. FRCP 9(b). A lack of particularity indicates that plaintiffs are just tacking on fraud as a last point without trying to develop a specific fraud theory. A number of cases reject fraud claims for lack of particularity. See, for example, Kottle, 146 F3d at 1063 (denying the claim because the plaintiff failed to state what the misrepresentations were and expressing concerns about chilling First Amendment rights); Music Center SNC Di Luciano Pisoni \& Co v Prestini Musical Instruments Corp, 874 F Supp 543, 549 (E D NY 1995) (disallowing claim for lack of specificity); Alfred Weissman Real Estate, Inc v Big V Supermarkets, Inc, 707 NYS2d 647, 268 A2d 101, 107 (App Div NY 2000) (stating that specific allegations are necessary in order not to chill legitimate lobbying activities). Plaintiffs should have this type of information at the commencement of a lawsuit because both plaintiff and defendant are probably competitors in an industry.

130 See text accompanying notes $84-89$.

$131146 \mathrm{~F} 3 \mathrm{~d}$ at 1060 (stating that if alleged anticompetitive behavior consists of misrepresentation or fraud then it will be deemed a sham and "deprive the litigation of its legitimacy").

132 472 US at $483-85$ (finding malice destroys absolute immunity protection of right to petition).

133 See Primetime 24 Joint Venture $v$ National Broadcasting Co, 219 F3d 92, 103 (2d Cir 
case (which $M c D o n a l d$ is), a plaintiff must allege injury to claim damages. ${ }^{134}$ Thus, Armstrong and Kottle do not reflect the limitations on the right to petition implied by the framework the Supreme Court has given to that right in McDonald and New York Times.

A fraud exception to the Noerr-Pennington doctrine makes sense. The First Amendment justification for Noerr-Pennington disappears when it protects fraud or misrepresentation. Since well-developed case law concerning fraud already exists, courts should be able to apply the exception to Noerr-Pennington with relative ease.

\section{APPLYING THE FRAUD EXCEPTION TO ADMINISTRATIVE AGENCY PROCEEDINGS USING THE FACT-SPECIFIC STANDARD}

A different set of rules should govern whether the fraud exception applies in administrative actions. Recall that Congress purposefully included elements of judicial and legislative functions when creating the APA's rulemaking and adjudicatory processes. ${ }^{135}$ California Motor makes an explicit distinction between activity in the "political arena" and the "adjudicatory process." the right to petition the government, but on the premise that the antitrust laws do not regulate political activity. ${ }^{137}$ Working from the assumption that the fraud exception exists in the judicial setting, the question for the administrative setting becomes whether the proceeding is judicial or legislative in nature. In California Motor, the Court equates legislative activity with rulemaking and judicial proceedings with the adjudicatory process. ${ }^{1.8}$ The Sherman Act considers company actions in the adjudicatory process as business activity. ${ }^{139}$ Hence, antitrust liability applies when companies commit fraud in the adjudica-

2000) ("In addition, a plaintiff must independently show 'antitrust injury' in order to ensure that 'a plaintiff can recover only if the loss stems from a competition-reducing aspect or effect of the defendant's behavior."'), quoting Atlantic Richfield Co v USA Petroleum, 495 US 328, 334, 344 (1990) (internal quotation marks omitted).

134 McDonald, 472 US at 481 (stating that injuries suffered were not being appointed United States Attorney, an injured reputation and career as an attorney, and suffering humiliation, embarrassment, anxiety, and mental anguish).

135 See Part I.B.

136 See text accompanying notes 66-71.

137 See Noerr, 365 US at 136 ("We think it equally clear that the Sherman Act does not prohibit two or more persons from associating together in an attempt to persuade the legislature or the executive to take particular action with respect to a law that would produce a restraint or a monopoly.").

138 See text accompanying notes 66-71.

139 See California Motor, 404 US at 515 ("A combination of entrepreneurs to harass and deter their competitors from having 'free and unlimited access' to the agencies and courts, to defeat that right by massive, concerted, and purposeful activities of the group" violates the antitrust laws.). 
tory process, but they receive antitrust immunity when participating in the legislative process.

The fact-specific standard illuminates the dichotomy between political and adjudicatory proceedings. Judicial proceedings involve a fact-specific, particularized inquiry into a dispute between a relatively small number of parties. Thus, adjudicatory proceedings should exhibit the same characteristics. ${ }^{140}$ The specific procedures leading to an action's resolution should not matter as much as whether the character of the action itself is the defining of a broad policy or the settling of a factual dispute. Thus, this Comment argues that courts should determine whether an administrative agency proceeding is conducting a fact-specific particularized inquiry to determine if the NoerrPennington doctrine reaches that activity under the Sherman Act. This Part first discusses the elements of the fact-specific standard and then justifies its use.

\section{A. The Fact-Specific Standard and Its Workability}

In Part I.B, this Comment demonstrated that the line between rulemaking and adjudication is often blurry. The Supreme Court has also noted the difficulty of pigeonholing certain actions into the rulemaking or adjudicatory sphere. ${ }^{141}$ In Londoner $v$ Denver ${ }^{142}$ and $\mathrm{Bi}$ Metallic Investment Co v Colorado ${ }^{1 / 3}$ the Court distinguished between administrative and legislative proceedings in analyzing the right to be heard under the Due Process Clause. ${ }^{144}$ Because a small number of people were involved with individualized circumstances, the Court treated the proceeding as judicial in nature and enforced the right to be heard. ${ }^{\text {iss }}$ On the other hand, "[w] here a rule of conduct applies to more than a few people it is impracticable that everyone should have a direct voice in its adoption." ${ }^{146}$ The Court has noted that its decisions "represent a recognized distinction in administrative law between proceedings for the purpose of promulgating policy-type rules or standards, on the one hand, and proceedings designed to adjudicate

140 Alfred C.Aman, Jr. and William T. Mayton, Administrative Law 120-21 (West 1993) (explaining that agency adjudications resemble Article III courts exercising federal question jurisdiction).

141 See SEC v Chenery Corp, 332 US 194,202 (1947) (noting the need to give administrative agencies flexibility to handle specialized problems that may arise).

142210 US 373 (1908) (requiring a hearing to challenge tax assessments).

143239 US 441 (1915) (requiring a hearing for the same reason).

144 Id at 445-46 (distinguishing decisions that affect "a relatively small number of persons" with those that affect large populations, which, if everyone were allowed a right to be heard, would halt the government).

145 See Londoner, 210 US at 385.

146 Bi-Metallic, 239 US at 445. 
disputed facts in particular cases on the other. ${ }^{147}$ Thus, an appropriate standard for determining whether a proceeding is judicial or legislative is if the proceeding involves a fact-specific inquiry involving a limited number of parties. Like the malice standard noted in the judicial setting, the fact-specific standard brings with it significant case law for determining if a company's actions constitute business activity punishable under the Sherman Act. ${ }^{14}$ Courts allow agencies to proceed through adjudication where a fact-specific inquiry takes place..$^{499}$

Application procedures, such as licensing, provide an excellent example of a proceeding that meets the fact-specific standard. Armstrong, Kottle, and the example in this Comment's introduction fall in this category. ${ }^{150}$ A significant portion of antitrust cases implicating administrative procedures involves licensing or application procedures instead of the notice and comment procedures usually used in a rulemaking action. ${ }^{151} \mathrm{~A}$ licensing or application procedure can have a wide range of procedural formalities, but the heart of the dispute remains whether a company has met certain statutory requirements to merit a license or permit. The granting or rejecting of a license or application does not have far-reaching policy implications; rather, it only affects the parties involved in that factual determination.

Notice and comment proceedings, on the other hand, fall on the legislative side of the ledger because of their policy emphasis. ${ }^{152}$ These proceedings rely more heavily on value judgments than facts. ${ }^{1.33}$ Notice

147 United States $v$ Florida East Coast Railway Co, 410 US 224, 245 (1973) (holding that the ICC may but is not required to hold a hearing before making rules).

148 See note 139.

149 See, for example, NLRB v Bell Aerospace Co, 416 US 267, 294 (1974) (allowing adjudication in the area of employee-or-manager questions because of the large number of factual situations that would arise under the issue), revd on other grounds, NLRB v Hendricks County Rural Electric Membership Corp, 454 US 170 (1981).

150 See Parts II.A and II.B.

151 See, for example, Walker Process Equipment, Inc $v$ Food Machinery and Chemical Corp, 382 US 172, 173 (1965) (patent application); Hospital Building Co v Trustees of the Rex Hospital, 691 F2d 678, 682 (4th Cir 1982) (hospital need application); Clipper Exxpress v Rocky Mountain Motor Tariff Bureau Inc, 690 F2d 1240, 1246-47 (9th Cir 1982) (tariff amendments application); City of Kirkwood v Union Electric Co, 671 F2d 1173, 1180-81 (8th Cir 1982) (rate filings before FERC); Alexander v National Farmers Organization, 687 F2d 1173, 1195 (8th Cir 1982) (application to USDA to be qualified on various federal market orders of milk); Israel v Baxter Lab, Inc, 466 F2d 272, 274 (DC Cir 1972) (FDA drug application proceeding); Music Center S.N.C. Di Luciano Pisoni \& Co v Prestini Musical Instruments Corp, 874 F Supp 543, 547-48 (E D NY 1995) (antidumping petition); WIXT Television Inc v Meredith Corp, 506 F Supp 1003, 1025-26 (N D NY 1980) (FCC application for relocation of transmission facility); Association of Data Processing Service Organizations, Inc v Citibank, NA, 508 F Supp 91, 93 (S D NY 1980) (application to transfer data processing activities to a non-banking subsidiary).

152 Aman and Mayton, Administrative Law at 40 (cited in note 140) (noting that administrative agency power "necessarily" requires policy formulation).

153 Id at 58-60 (noting that rulemaking proceedings seek to meet statutory goals and seek broader sources of evidence than adjudications). 
and comment proceedings also tend to have a wider range of effects than on any two given parties. ${ }^{1.4}$ Antitrust laws were not meant to extend to these broader policy actions. ${ }^{2.55}$

Fraud claims also distinctly apply to situations where an administrative agency engages in a fact-specific inquiry. In policy-type proceedings, allegations are less subject to fraud or misrepresentation claims because they rely on broader social, political, or economic judgments. Fact-specific inquiries tend to be verifiable, discrete statements (for example, XYZ company made $\$ 30$ million last year). Because of First Amendment concerns, courts should not worry about the former but should be concerned about the latter, particularly if a factual assertion specifically hurts an individual claimant. Thus, the fact-specific standard places those fraud claims that uniquely apply to business activity (rather than political activity) within the reach of the Sherman Act.

\section{B. Justifications for the Fact-Specific Standard}

Two main justifications underlie the need for the fact-specific standard to determine whether the Sherman Act should apply to business actions before administrative agencies. First, this standard prevents companies from engaging in unfair competition through agency capture. Second, the fact-specific standard allows courts to act as a check on agency action.

\section{Agency capture.}

The Sherman Act promotes competition, prevents monopolization, and creates efficiency and equality of opportunity for companies. ${ }^{1 \text { ss }}$ A party winning an administrative claim based on fraudulent evidence wields the agency as a weapon to prevent a legitimate business from gaining a toehold in the market. Fraudulent submissions to such a body probably mean that the party intends to use the administrative process to delay its competitor by increasing entry costs. This scenario invokes what commentators term the "agency capture" the-

154 See National Small Shipments Traffic Conference, Inc v Interstate Commerce Commission, 725 F2d 1442, 1447-48 (DC Cir 1984) (comparing differences between "[t] $\mathrm{trial}-$ like procedures" and "[n]otice-and-comment procedures" and noting that the former is focused on individual parties while the latter is suited for rulemaking and policy in general); Aman and Mayton, Administrative Law at 101-02 (cited in note 140) (noting that administrative agency power necessarily requires policy formation).

155 See Noerr, 365 US at 138 ("[W]e think it clear that the Sherman Act does not apply to the activities of the railroads at least insofar as those activities compromised mere solicitation of governmental action with respect to the passage and enforcement of laws.").

156 See text accompanying notes 15-16. 
ory. ${ }^{157}$ Agency capture can occur when a company or an industry (usually led by dominant companies) exerts undue influence over an agency. A company could exercise monopoly power over an administrative agency and use the agency to maintain its monopoly power. This result hampers equality of opportunity by allowing older firms to shut out newer firms, and it hurts competition by entrenching certain players in heavily regulated markets. ${ }^{1.8}$ In this way, fraud undermines the legitimacy of certain administrative proceedings and merits liability. $^{150}$

Administrative agencies recognize that some companies use administrative processes to further anticompetitive goals. The Federal Trade Commission expressed concern that firms use frivolous litigation and petitions to the Food and Drug Administration to prevent or slow down new entrants and thus deter competition. ${ }^{160}$ Plaintiffs have alleged abuse of the Interstate Commerce Commission, the Federal Communications Commission, the Federal Energy Regulatory Commission, the Nuclear Regulatory Commission, the Department of Agriculture, the old Civil Aeronautics Board, the Department of Commerce, the Federal Reserve Board, and a host of state and local agencies. ${ }^{161}$ The economic rationale for these actions is simple: an incumbent firm can use administrative proceedings to delay entry of new

157 See William W. Bratton and Joseph A. McCahery, Regulatory Competition, Regulatory Capture, and Corporate Self-Regulation, 73 NC L Rev 1861, 1885-88 (1995); Jonathan R. Macey, Administrative Agency Obsolescence and Interest Group Formation: A Case Study of the SEC at Sixty, 15 Cardozo L Rev 909, 913-14 (1994); John Shephard Wiley, Jr., A Capture Theory of Antitrust Federalism, 99 Harv L Rev 713, 723-26 (1986); Richard B. Stewart, The Reformation of American Administrative Law, 88 Harv L Rev 1669, 1684-87 (1975). Another version under which agency capture can occur involves agency bureaucrats becoming so closely identified with the company or industry that they work as tools of the company's or industry's interests. See, for example, John F. Manning, Constitutional Structure and Judicial Deference to Agency Interpretations of Agency Rules, 96 Colum L Rev 612, 677 n 308 (1996) (“Agency capture' refers to domination of an agency by the entities that the agency was created to control.").

158 Environmental regulation provides an excellent example. Environmental regulation helps larger companies because they can absorb the red tape better than can small companies. See B. Peter Pashington, The Effect of Environmental Regulation on Optimal Plant Size and Factor Shares, 27 J L \& Econ 1, 25-26 (1984) (showing that environmental regulation has placed a greater burden on small plants).

159 There is also a strict statutory reason for finding liability. See 18 USC § 1001 (1994 \& Supp 2001) (criminalizing "knowingly and willfully" misrepresenting a material fact or statement).

160 See Testimony of Mark D. Whitener, Acting Deputy Director, FTC Bureau of Competition, before the Senate Special Committee on Aging, 103d Cong, 1st Sess 102 (1993) ("Another ongoing investigation involves the possible abuse of regulatory processes by an incumbent firm in order to defeat or retard market entry by a competitor. Judicial and regulatory proceedings can be the principal hurdles faced by new entrants into pharmaceutical markets."); Mark D. Whitener, Competition and Antitrust Enforcement in the Changing Pharmaceutical Marketplace, 50 Food \& Drug L J 301, 307 (1995). The hypothetical in the introduction shows a prototypical case of abuse of regulatory process.

161 See Noah, 74 NC L Rev at 11-14 (cited in note 1). 
products and increase transaction costs for competitors. ${ }^{162}$ Administrative proceedings, much more so than judicial proceedings, tend to rely on the information that the parties provide to them. ${ }^{163}$ These agencies lack the necessary funds to verify the accuracy of every allegation. ${ }^{16}$ Because of these concerns, some administrative agencies have gone so far as to ask the courts to impose antitrust liability against those who abuse the process to help deter future action. ${ }^{165}$

Thus, in those circumstances in which agencies lack the resources to verify facts in applications, permits, and licenses, the judiciary provides an excellent backstop to prevent fraudulent applications by companies. Egregious examples of fraud that hurt competition will lead to lawsuits brought by companies harmed by an improper ruling. ${ }^{166}$ Because of the heightened pleading requirements, courts can quickly find the claims that might have merit and avoid prolonged litigation. Obviously, this system will not catch all instances of fraud and misrepresentation. Some meritorious claims may slip through because a plaintiff does not have information to plead with particularity. With broad civil discovery rules and the threat of treble damage liability, however, these rules should promote more truthful submissions by companies in agency proceedings.

Courts will also have the benefit of agency expertise because they can come in as amici curiae. Clipper Exxpress v Rocky Mountain Mo-

162 See Robert H. Bork, The Antitrust Paradox: A Policy at War with Itself 364 (Free Press 1993) ("Predation through the misuse of government processes appears to be a common but little-noticed phenomenon."); James D. Hurwitz, Abuse of Governmental Processes, the First Amendment, and the Boundaries of Noerr, 74 Georgetown L J 65, 69 (1985) (discussing how abuse of government processes increases a predator's power).

163 Clipper Exxpress v Rocky Mountain Motor Tariff Bureau Inc, 690 F2d 1240, 1261 (9th Cir 1982) ("In the adjudicatory sphere, however, information supplied by the parties is relied on as accurate for decision making and dispute resolving."); Allied Tube \& Conduit Corp v Indian Head, Inc, 486 US 492, 499-500 (1988) (explaining the "serious potential for anticompetitive harm" inherent in administrative agencies and other standards setting associations' rulemaking power). Note how this is a different result from the adversarial process in a litigation setting, where parties submit each others' evidence to thorough scrutiny.

164 See, for example, Clipper Exxpress, $60 \mathrm{~F} 2 \mathrm{~d}$ at 1262 (noting that agencies rarely have the time or funds to verify facts). For this reason Noah's conclusion that "agencies may need to assume greater responsibility for controlling the behavior of participants in administrative proceedings," Noah, 74 NC L Rev at 73 (cited in note 1), is suspect. Forcing administrative agencies to back-check every allegation of fact made in a proceeding is extremely burdensome and costly. Quickly the complaints would turn against the government for being so intrusive in such routine matters. Indeed, a number of petitions are legitimate and a great number will present valuable information. The threat of treble damages from antitrust liability would probably chill companies' desire to knowingly present false information and make administrative proceedings more accurate in the end. See 15 USC $\$ 15$ (providing for treble damages).

165 See Clipper Exxpress, 690 F2d at 1262 n 34 (noting the ICC only had a small staff to monitor the actions of litigants and had to rely on the parties to tell the truth and that the treble damages provision of the antitrust laws would likely provide an incentive to bring to light such wrongdoing).

165 See Part III. 
tor Tariff Bureau, $I n c^{167}$ provides an excellent example. In Clipper, the Interstate Commerce Commission filed an amicus curiae brief to inform the court of its position regarding its tariff amendments application process. ${ }^{1.8}$ It informed the court that it lacked the resources to check the information contained in the applications and offered its opinion on the application. ${ }^{169}$ Thus, the fact-specific standard leads to a world where budget-strapped, aggrieved agencies can turn to the courts for relief from fraudulent practices without courts being deprived of agencies' expertise on those matters.

\section{Checking agency action.}

Unlike the now-defunct ICC, many agencies have procedures and resources to audit information given them by companies applying for licenses, permits, amendments and so forth. ${ }^{170}$ Some agencies even impose penalties for submitting bad information. ${ }^{171}$ Even under these conditions, however, courts act as a check on agency action.

Courts give agencies leeway in their determinations. Courts must allow an agency's reasonable interpretation of an ambiguous congressional mandate to stand. ${ }^{12}$ Courts also sometimes grant agencies significant leeway in their conclusions of fact. ${ }^{173}$ This deference will vary according to the agency and congressional mandate. ${ }^{174}$ Agencies have greater expertise than the courts in those areas, so this general deference seems justified.

There must be boundaries to agency discretion. The APA allows courts to overturn final agency actions that meet an "arbitrary and ca-

167690 F2d 1240 (9th Cir 1982).

168 Id at $1262 \mathrm{n} 34$.

169 Id.

170 See, for example, 19 CFR $\S 351.307$ (2001) (authorizing the Secretary of Commerce to verify factual information); 17 CFR $\$ 202.5$ (2001) (discussing investigative methods available to Securities and Exchange Commission).

171 See, for example, 8 CFR $\$ 292.3$ (a) (2001) (discussing penalties available to the Board of Appeals to impose on parties such as expulsion, suspension and censure in immigration matters); 37 CFR $\S 10.18$ (b) (2001) (authorizing the use of sanctions such as termination of patent proceedings, delay, and money); 47 CFR $\$ 1.52$ (2000) (discussing the ability of the Federal Communications Commission to strike various documents as sham or false if the information is incorrect or the proper procedure is not followed).

172 See Chevron USA Inc v Natural Resources Defense Council, Inc, 467 US 837, 843-44 (1984) (requiring deference to agency interpretations of statutes).

173 See, for example, Interstate Commerce Commission v Brotherhood of Locomotive Engineers, 482 US 270, 282 (1987), quoting 5 USC $\$ 701(a)(2)$ (1994) (noting a "tradition of [judicial] nonreviewability exists with regard to refusals to reconsider for material error," which tradition 5 USC $\S 701$ (a)(2) codifies by precluding review "to the extent that ... agency action is committed to agency discretion by law").

174 See, for example, United States v Mead Corp, 121 S Ct 2164, 2177 (2001) (holding that tariff classification rulings by the United States Customs Service receive minimal deference). 
pricious" standard. ${ }^{175}$ Also, several statutes specifically allow for judicial review of agency determinations. ${ }^{176}$ Given this structure, courts act as a check on agency abuse of discretion, possibly to keep agencies from acting narrow-mindedly. ${ }^{1 m}$ Even though courts lack agency expertise in certain areas, they understand antitrust law and fraud claims better than agencies do. ${ }^{178}$ Courts frequently determine if an agency's decision is based on fraudulent evidence and have the power to overturn that decision. The involvement of an antitrust claim does not change that picture. ${ }^{179}$ In fact, the inclusion of antitrust liability increases the penalty for fraud because of its treble damages provision. Agency regulations do not hold the exclusive means for punishing fraudulent information. Thus, the fact-specific standard remains intact even if an agency has its own ways to find and punish fraudulent information.

Finally, the fact-specific standard is superior to Kottle and Armstrong's respective approaches to determining whether an agency should be subject to the fraud exception. Neither case articulated a definitive standard and both allowed for broad ranges of judicial interpretation. In particular, the Ninth Circuit admitted that it had not "clearly resolv[ed] the scope" of the sham exception in administrative proceedings. ${ }^{150}$ This unarticulated standard risks chilling legitimate free speech. While the Court has exercised caution and is willing to risk some falsehood to promote free debate, a clearer standard will encourage businesses to be more diligent in their statements without preventing them from talking at all. ${ }^{181}$

175 See 5 USC $\$ 706(2)(A)$ (1994). For an application of this standard, see Motor Vehicle Manufacturers Association of the United States, Inc v State Farm Mutual Automobile Insurance Co, 463 US 29, 46 (1983) (holding that an order by the National Highway Traffic Safety Administration rescinding certain crash protection requirements was arbitrary and capricious).

176 See, for example, 16 USC $\$ 1536$ (n) (2000) (allowing judicial review of decisions reached by the Endangered Species Committee).

177 See, for example, Bennett $v$ Spear, 520 US 154, 176-77 (1997) (noting concern that National Fish and Wildlife Service focuses so much on environmental considerations that it fails to consider legitimate economic concerns).

178 Consider Michael Asimow, The Scope of Judicial Review of Decisions of California Administrative Agencies, 42 UCLA L Rev 1157, 1219 (discussing the competence of courts compared to administrative agencies in applying overarching statutes and common law to the facts).

179 See, for example, Walker Process Equipment, Inc v Food Machinery \& Chemical Corp, 382 US 172, 175-77 (1965) (holding that the enforcement of a patent procured by intentional fraud on the patent office may violate the Sherman Act, provided the other elements necessary to a Sherman Act violation are present).

180 Kottle, 146 F3d at 1062 (noting that while the scope of the immunity is unclear in administrative proceedings, it "depends on the degree of political discretion exercised by the government agency"), citing Forro Precision, Inc v IBM, 673 F2d 1045, 1060 (9th Cir 1982).

181 See Gertz v Robert Welch, Inc, 418 US 323, 341 (1974) ("The First Amendment requires that we protect some falsehood in order to protect speech that matters."). 
Overall, this standard gives courts significantly more guidance in determining whether or not an administrative process is political or adjudicatory. It also protects First Amendment concerns by allowing debate in the political arena while giving the Sherman Act its full strength by regulating fraudulent business activity.

\section{CONCLUSION}

Let us return to the hypothetical posed at the beginning of this Comment. Stephenson and Cushing have intentionally blocked Flanigan from a legitimate opportunity to participate in a market by thwarting an administrative process designed to promote fair competition. This Comment has shown that the right to petition does not extend to the lengths that many defendant companies, such as Stephenson and Cushing, assert. Since the Noerr-Pennington doctrine rests on the right to petition, it should not be allowed to go further than the right itself. Two important goals are achieved by establishing a wellreasoned fraud standard based on existing precedent and properly tailoring antitrust laws to apply to adjudicatory processes achieves two important goals. First, administrative agencies will receive better information from parties. Second, agencies will render more accurate decisions. The fraud exception helps promote the purposes of the antitrust laws by ensuring that competition takes place on fair ground. Under this standard, Flanigan should have a fair chance of receiving approval for its drug based on the merits, rather than being frustrated by the misrepresentations of its competitors. 